Article

\title{
Environmental Impact of a Mass Timber Building-A Case Study
}

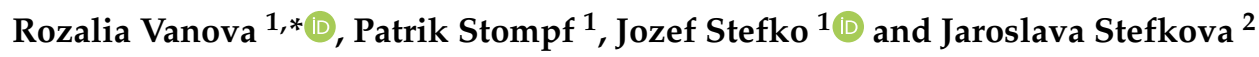 \\ 1 Department of Wood Structures, Faculty of Wood Sciences and Technology, Technical University in Zvolen, \\ 96001 Zvolen, Slovakia; xstompf@is.tuzvo.sk (P.S.); stefko@tuzvo.sk (J.S.) \\ 2 Institute of Foreign Languages, Technical University in Zvolen, 96001 Zvolen, Slovakia; \\ jaroslava.stefkova@tuzvo.sk \\ * Correspondence: xvanova@is.tuzvo.sk; Tel.: +42-14-5520-6541
}

Citation: Vanova, R.; Stompf, P.; Stefko, J.; Stefkova, J. Environmental Impact of a Mass Timber Building-A Case Study. Forests 2021, 12, 1571. https://doi.org/10.3390/f12111571

Academic Editors: Jānis Brizga and Joana Amaral Paulo

Received: 26 October 2021

Accepted: 12 November 2021

Published: 15 November 2021

Publisher's Note: MDPI stays neutral with regard to jurisdictional claims in published maps and institutional affiliations.

Copyright: (C) 2021 by the authors. Licensee MDPI, Basel, Switzerland. This article is an open access article distributed under the terms and conditions of the Creative Commons Attribution (CC BY) license (https:/ / creativecommons.org/licenses/by/ $4.0 /)$.

\begin{abstract}
The study focuses on a life cycle assessment of a wood-based residential building and evaluates the magnitude of individual construction components-foundations, flooring, peripheral wall, inner walls, ceiling, roof, windows, and doors-in terms of climate change; acidification; eutrophication; photochemical oxidation; depletion of abiotic elements and fossil fuels; and water scarcity categories within the system boundaries of the Product stage of the life cycle. The assessment was done using the SimaPro software and the ecoinvent database. The results pointed at the advantages of mass timber as a construction material and highlighted the significance in the type of insulation used. Foundations were found to bear the highest share of impact on photochemical oxidation reaching nearly $30 \%$ and depletion of fossil fuels accounting for about $25 \%$ of that impact. Peripheral wall was ranked the worst in terms of impact on acidification and eutrophication (more than $25 \%$ of both), depletion of elements (responsible for $50 \%$ of that impact), and had about $60 \%$ impact on water scarcity. After adding up carbon emissions and removals, the embodied impact of the whole construction on climate change was detected to be $8185.19 \mathrm{~kg} \mathrm{CO}_{2}$ eq emissions which corresponded with $57.08 \mathrm{~kg} \mathrm{CO}_{2} \mathrm{eq} / \mathrm{m}^{2}$ of gross internal area. A negative carbon composition of the construction was also set.
\end{abstract}

Keywords: mass timber; construction materials; life cycle assessment; environmental impact; sustainability; embodied impact

\section{Introduction}

The building sector accounts for relevant participation in general greenhouse gas emissions. Several climate declarations have been approved in a bid to reduce the climate impact from the building sector in everything that is built [1-3]. These focused climate declarations are a part of the shift towards a reduced climate impact from buildings from a life-cycle perspective, and they aim to drive developments towards more sustainable construction.

Cross-laminated timber (CLT) is a widely used engineered timber product in constructions, applicable as a full-size wall and floor element as well as a linear timber member, through the orthogonal laminar structure [4]. CLT is "a prefabricated engineered wood product consisting of at least three layers of solid-sawn timber or structural composite lumber where the adjacent layers are cross-oriented and bonded with structural adhesive to form a solid wood element" [5] (Figure 1). According to Karacabeyli and Brad [6], it is suitable as a structural or non-structural material for constructing walls, floors, ceilings, roofs, etc. Due to the cross-orientation of layers, CLT has a structural capability of a two-way span, desirable for floor applications. 


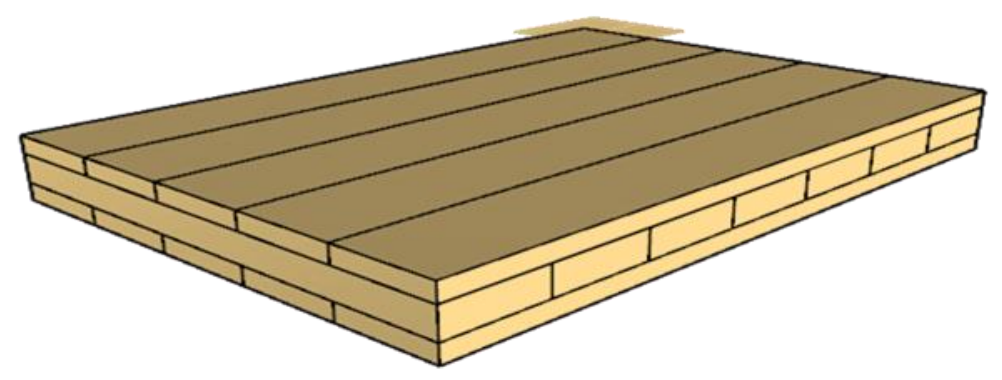

Figure 1. Cross-laminated timber panel.

CLT is a construction material in the building which represents a sustainable way of construction with minimal environmental impact $[7,8]$. CLT is a relatively new progressive but proven technology that can replace environmentally more encumbering building materials in many building applications.

International Organization for Standardization (ISO) and the European Committee for Standardization (CEN) both have sets of standard documents defining the environmental assessment process for construction materials and buildings. Life Cycle Assessment (LCA) is an analytical method evaluating the impact of products, services, and organizations on the environment under the conditions set by ISO 14040 and $14044[9,10]$ through several categories, of which global warming or climate change are the most common. Specific standards for LCA in the construction sector include CEN's EN 15978 [11] as a part of standards for assessing the environmental performance of a building and ISO 21931-1 [12] dealing with buildings sustainability.

By Robertson et al. [13], increased availability of readily accessible potential energy stored within the building materials of the timber alternative is indicated in a comparative cradle-to-gate life cycle assessment of building construction alternatives (Laminated Timber or Reinforced Concrete). Regarding a cradle-to-grave assessment by Liu et al. [14] replacement of masonry structure with CLT panel led to a reduction of energy consumption by more than $30 \%$ and decrease of $\mathrm{CO}_{2}$ emission by more than $40 \%$. As reported in an environmental product declaration (certificate needed for a building materials market) [15], a CLT frame manufactured by Södra can reduce carbon emissions by up to 80 percent compared with a similar concrete frame.

The study by Pierobon et al. [8] focused on the environmental benefits of using hybrid CLT structures in midrise non-residential constructions. The results showed that an average of $26.5 \%$ reduction in the global warming potential is achieved in the hybrid CLT building compared to the concrete building. Moreover, the non-renewable energy (fossil-based) used in the hybrid CLT building is $8 \%$ lower compared to that of the concrete structure. As global warming is the most frequently used impact category to determine building environmental performance, other categories are rarely stated. By the study of Chen et al. [16], the mass timber building had 18,1 , and $47 \%$ reduction in the impact categories of global warming, ozone depletion, and eutrophication, respectively, compared with a similar concrete building.

LCA environmental evaluation of CLT as a material itself is reported in several published studies $[7,14,17,18]$, while logistics and wood species mix have an essential impact on the final assessment [19]. However, the generalizations in case studies on whole building life cycle assessment are limited by case-to-case type, exploitation, geometry (shape) of building [20], and the combination of materials in hybrid constructions.

Despite certain similarities, each wood-based construction composition might be different depending on the used materials, which consequently affect the embodied impact of the building. Moreover, Bahramian and Yetilmezsoy [21] compared LCA studies on buildings over two decades. They identified numerous parameters such as life span, functional unit, life cycle stages, and impact categories to vary from study to study, making it difficult to compare buildings with each other. 
This paper identifies the environmental performance of a typical wood-based reference residential building based on massive CLT as the frame construction material in terms of embodied impact on the environment. The structure is divided into construction sections-foundations, flooring, peripheral wall, inner walls, ceiling, roof, windows, and doors-and evaluated through climate change; acidification; eutrophication; photochemical oxidation; depletion of abiotic elements and fossil fuels; and water scarcity. The structure is also compared to a similar construction system replacing CLT for MHM (Massive Holz Mauer) panels. The study's outcomes provide information on the possible environmental impact of a massive timber building and might help designers, developers, and resellers in the building industry to critically assess the sustainability of natural-based construction materials.

\section{Materials and Methods}

\subsection{Reference Unit and System Boundaries Description}

The unit of the study was represented by the whole single-story residential building with a compact shape designed for a family of four to six members (Figures 2-4). The floor plan solution was ready-made by Inardex, Co. (Trenchin, Slovakia) [22] and the construction composition was adjusted by the authors to meet the passive building target values of heat transfer coefficient given by the Slovak Technical Standard [23]. The load-bearing structure consisted of a solid wood panel system based on CLT. The foundations consisted of a reinforced concrete ground slab. The gable roof structure was supported with trusses. Dimensions of the CLT panel were 120-mm thick in the peripheral wall and 80-mm thick in partitions. The material composition was composed mainly of natural construction materials, such as CLT panel, glued solid timber and oriented strand board. The thermal insulation consisted of wood fiberboards placed in a supporting grid of I-profile beams. The external layers of the structure consisted of a wood fiber thermal insulation contact system and wood cladding. The heat transfer coefficient of peripheral wall was calculated according to the Slovak Technical Standard [23] and equaled to $0.141 \mathrm{~W} \cdot \mathrm{m}^{-2} \mathrm{~K}^{-1}$. Aluminum frame windows with triple glazing were used. The measures of the construction were defined by the gross external area of $174.2 \mathrm{~m}^{2}$; gross internal area of $148.5 \mathrm{~m}^{2}$, and net internal area of $142.1 \mathrm{~m}^{2}$.

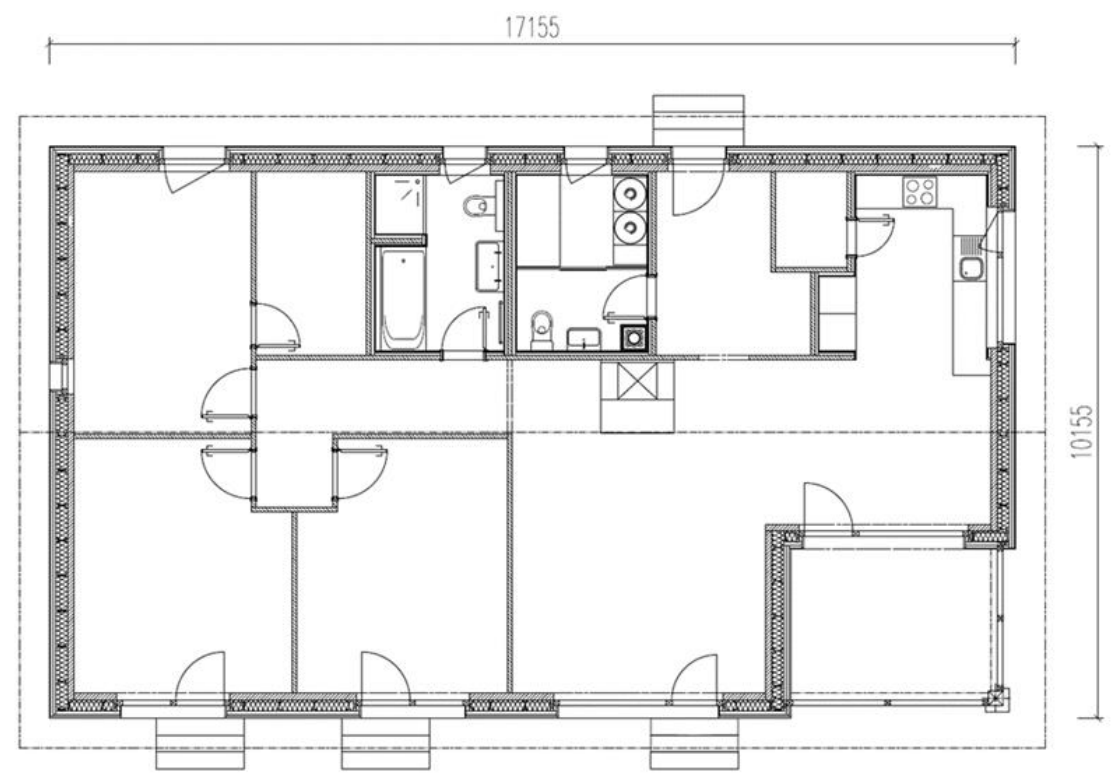

Figure 2. Floor plan of the construction. 


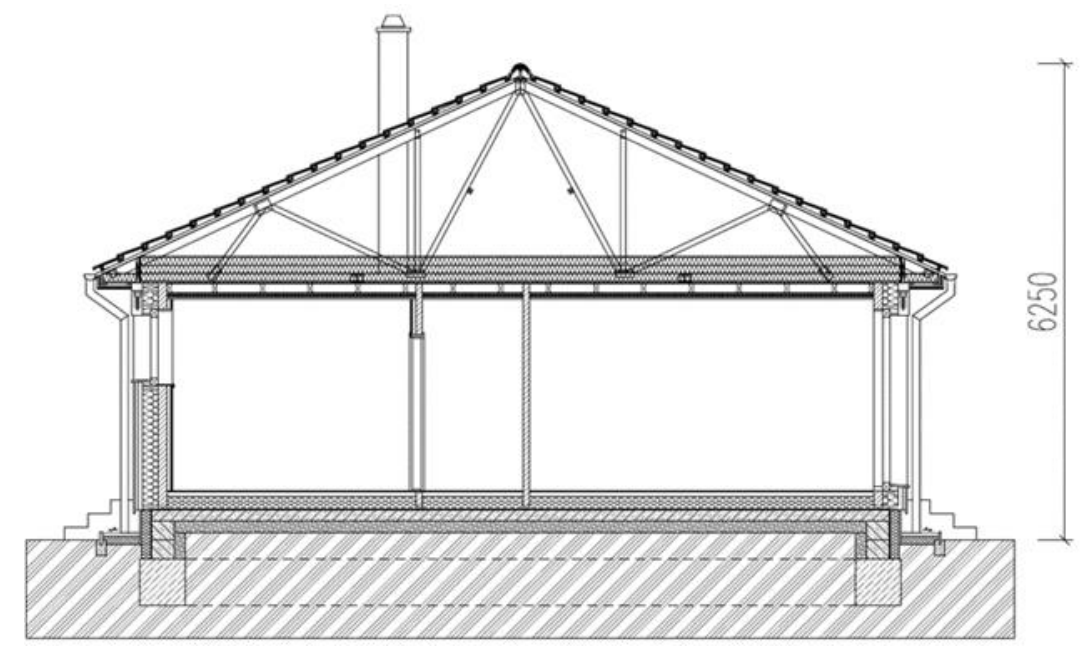

Figure 3. Cross-section of the construction.

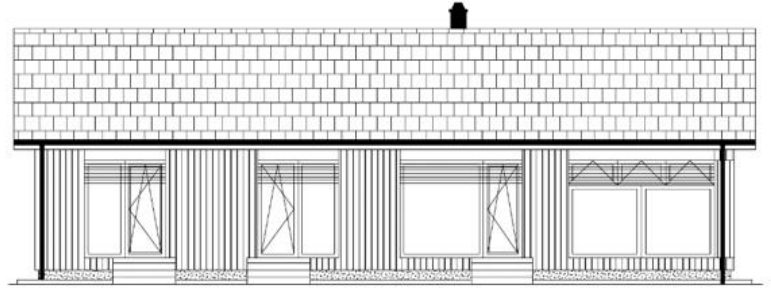

(a)

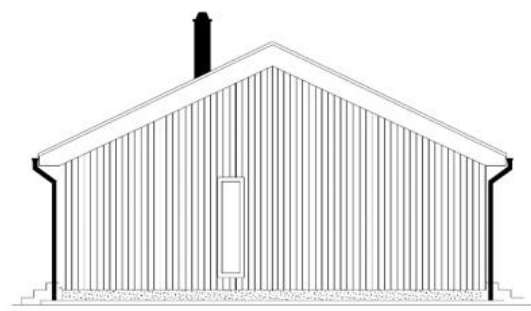

(c)

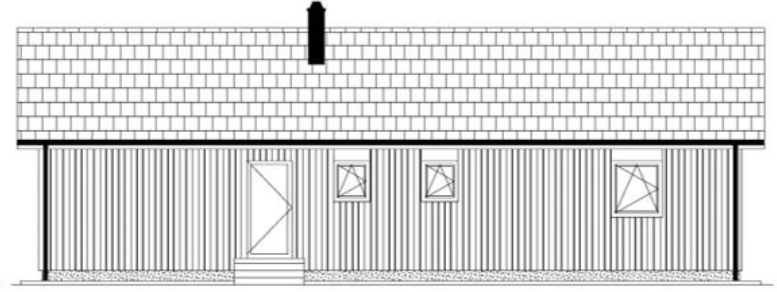

(b)

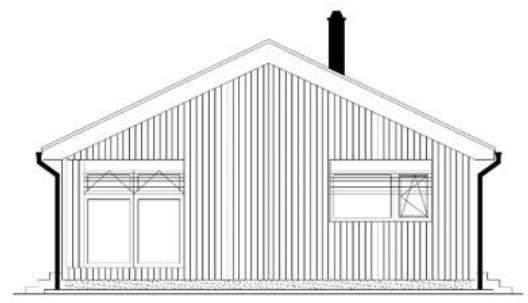

(d)

Figure 4. Front views of the construction: (a) western view; (b) eastern view; (c) northern view; and (d) southern view.

The object was assessed according to ISO 14040 and $14044[9,10]$. System boundaries (Figure 5) were chosen from A1-A3 by EN 15804 [24]. The evaluation was done using SimaPro 9.2.0.2 Analyst [25], developed by PRé Consultants in The Netherlands. Ecoinvent 3.7.1 database [26] was chosen as a source of input data for life cycle inventory. Calculation methods were chosen as follows: for the climate change (CC) impact category, IPCC 2013 GWP 100a (including $\mathrm{CO}_{2}$ uptake) v1.00 method [27] was used; for the rest impact categories, EPD (2018) v1.02 method was selected [28].

For the assessment purposes, the construction was divided into foundations, flooring, peripheral walls, inner walls, ceiling, roof, windows, and doors. Description of construction materials within each component and specification of the input database are given in Table 1. 


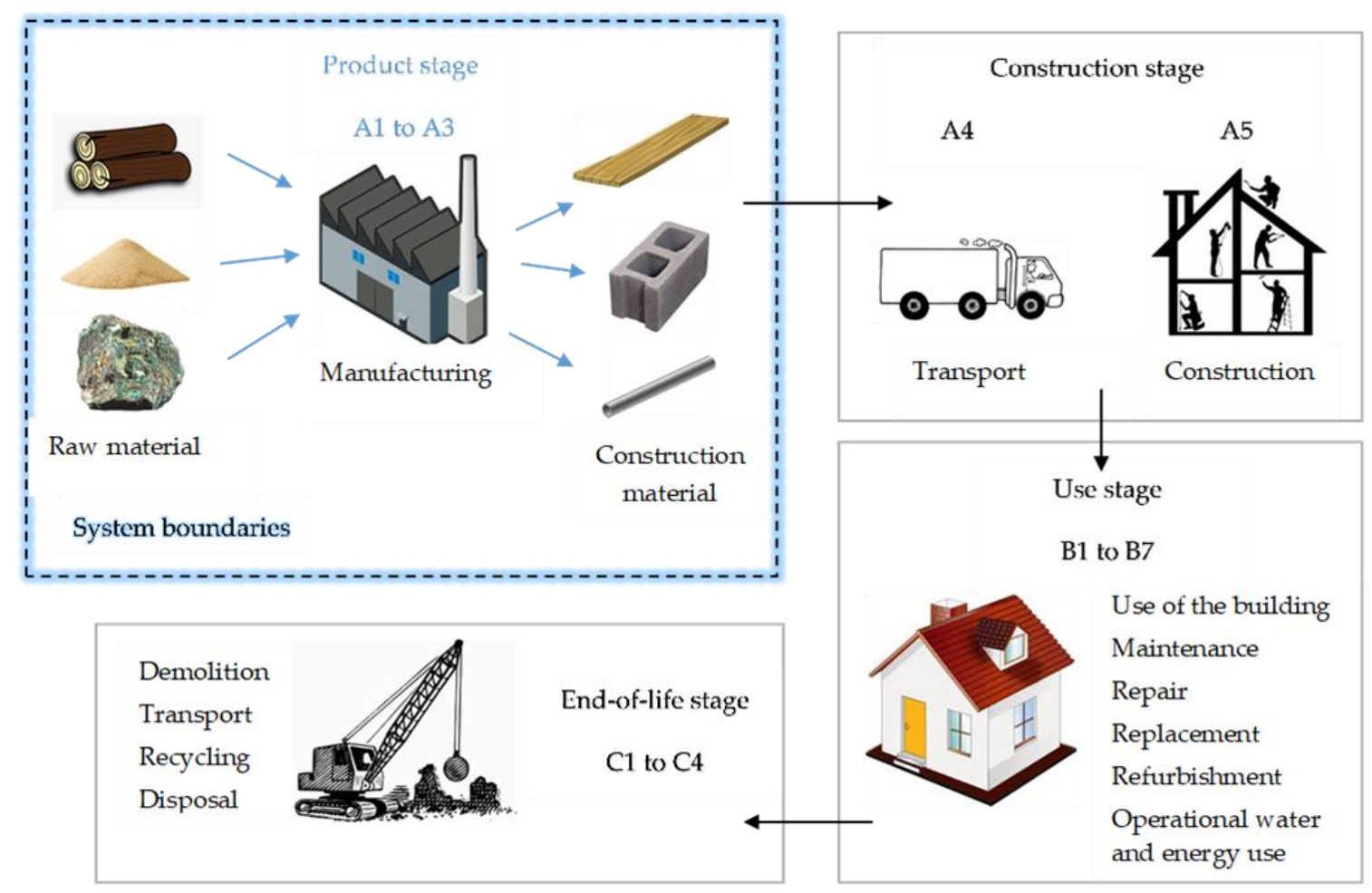

Figure 5. System boundaries.

Table 1. Description of construction composition and databases selected for the assessment of the building within life cycle stages from A1-A3.

\begin{tabular}{|c|c|c|}
\hline Component & Material & Specification of the Chosen Database \\
\hline Foundations & $\begin{array}{l}\text { Concrete } \\
\text { Steel } \\
\text { Gravel }\end{array}$ & $\begin{array}{c}\text { Concrete block }\{\text { RoW }\} \text { I market for concrete block I APOS, S } \\
\text { Concrete, } 20 \mathrm{MPa}\{\text { RoW }\} \text { | market for concrete, } 20 \mathrm{MPa} \text { | APOS, S } \\
\text { Concrete, 25-30 MPa }\{\text { RoW } \mid \text { market for concrete, 25-30 MPa I APOS, S } \\
\text { Reinforcing steel }\{\text { GLO\} I market for I APOS, S } \\
\text { Gravel, crushed }\{\text { RoW }\} \text { I market for gravel, crushed I APOS, S }\end{array}$ \\
\hline Flooring & $\begin{array}{l}\text { Waterproof layer } \\
\text { Insulation } \\
\text { Mortar } \\
\text { Wood floor } \\
\quad \text { Tiling }\end{array}$ & $\begin{array}{c}\text { Bitumen seal, Alu80 \{RER }\} \text { | production I APOS, S } \\
\text { Polystyrene foam slab }\{\text { GLO } \mid \text { | market for I APOS, S } \\
\text { Adhesive mortar }\{\text { RoW }\} \text { | production I APOS, S } \\
\text { Cement mortar }\{\text { RoW } \mid \text { market for cement mortar I APOS, S } \\
\text { Three and five-layered board }\{\text { RER }\} \text { | market for three and five-layered } \\
\text { board I APOS, S } \\
\text { Ceramic tile }\{\text { GLO } \mid \text { | market for I APOS, S }\end{array}$ \\
\hline Peripheral wall & $\begin{array}{l}\text { Inner sheating } \\
\text { Mortar } \\
\text { Steel joints } \\
\text { Inner tiling } \\
\text { Plinth tiling } \\
\text { Outer sheating }\end{array}$ & 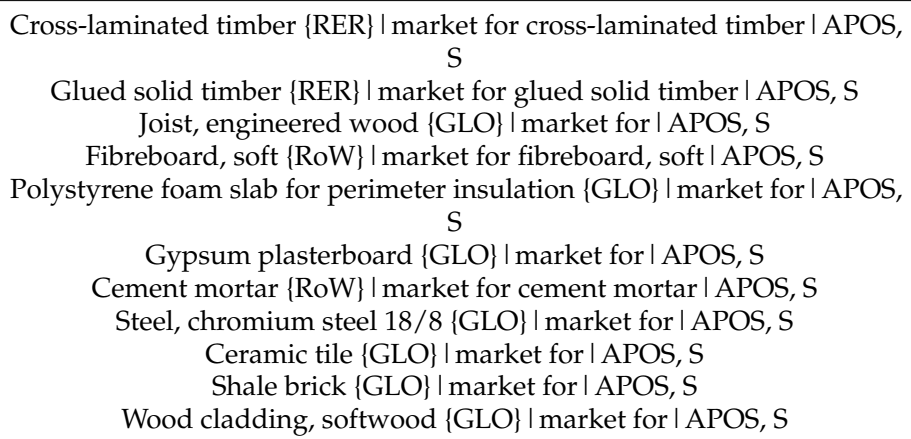 \\
\hline
\end{tabular}


Table 1. Cont.

\begin{tabular}{|c|c|c|}
\hline Component & Material & Specification of the Chosen Database \\
\hline Inner walls & $\begin{array}{l}\text { Timber } \\
\text { Sheating } \\
\text { Tiling } \\
\text { Steel joints } \\
\text { Mortar }\end{array}$ & 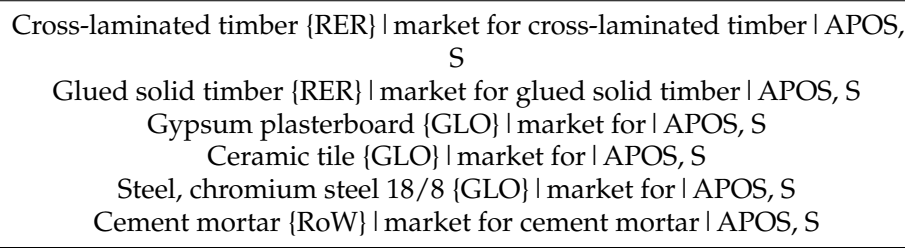 \\
\hline Ceiling & $\begin{array}{l}\text { Timber } \\
\text { Sheating } \\
\text { Insulation } \\
\text { Steel joints }\end{array}$ & $\begin{array}{l}\text { Glued solid timber }\{\text { RER }\} \text { | market for glued solid timber | APOS, S } \\
\text { Gypsum plasterboard }\{\text { GLO } \mid \text { market for I APOS, S } \\
\text { Oriented strand board }\{\text { RER }\} \text { I market for oriented strand board I APOS, S } \\
\text { glass wool mat, uncoated, Saint-Gobain ISOVER SA }\{\mathrm{CH}\} \text { I market for } \\
\text { glass wool mat, uncoated, Saint-Gobain ISOVER SA I APOS, U } \\
\text { Cellulose fibre }\{\text { RoW }\} \text { | market for cellulose fibre I APOS, S } \\
\text { Steel, chromium steel } 18 / 8\{\text { GLO } \mid \text { I market for I APOS, S }\end{array}$ \\
\hline Roof & $\begin{array}{c}\text { Timber } \\
\text { Insulation } \\
\text { Steel joints } \\
\text { Roof tiles } \\
\text { Water drainage system } \\
\text { Chimney }\end{array}$ & 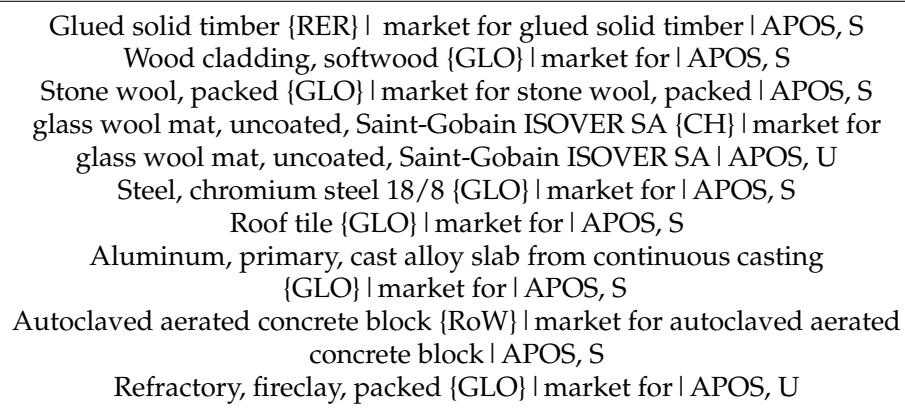 \\
\hline Windows and doors & $\begin{array}{l}\text { Window frame } \\
\text { Glazing } \\
\text { Outer door } \\
\text { Inner door }\end{array}$ & $\begin{array}{c}\text { Window frame, aluminium, } \mathrm{U}=1.6 \mathrm{~W} / \mathrm{m} 2 \mathrm{~K}\{\mathrm{GLO}\} \mid \text { market for } \mid \mathrm{APOS}, \mathrm{S} \\
\text { Glazing, triple, } \mathrm{U}<0.5 \mathrm{~W} / \mathrm{m} 2 \mathrm{~K}\{\mathrm{GLO}\} \mid \text { market for } \mid \mathrm{APOS}, \mathrm{S} \\
\text { Door, outer, wood-aluminium }\{\mathrm{GLO}\} \text { | market for | APOS, S } \\
\text { Door, inner, wood }\{\mathrm{GLO}\} \text { | market for I APOS, S }\end{array}$ \\
\hline
\end{tabular}

Note: APOS—Allocation at the point of substitution; S-System processes; U—unit processes; GLO_global data; RER-data representative for Europe; RoW-data representative for rest of the world.

\subsection{Data Quality Statements}

The selected structure was designed by the authors. Data on input construction materials were calculated based on the actual dimensions of the compounds and represent Europe's geographical region. All relevant input flows were included meeting the 1\% cut-off rule. The data are representative of the current year.

\section{Results}

\subsection{Weight and Volume Distribution}

First, the weight and volume of the construction components were assessed (Figure 6). Foundations occupied the majority $(76.68 \%)$ of the overall weight distribution. Peripheral wall $(7.30 \%)$ and roof $(6.70 \%)$ were the second and third heaviest, respectively. The rest component distribution was below 5\%. By volume, the most significant share was represented by the ceiling $(28.89 \%)$, followed by the peripheral wall $(23.23 \%)$, foundations $(19.25 \%)$, and flooring $(14.12 \%)$. The contribution of other components reached a maximum of $6.39 \%$ in the case of the roof.

CLT panels were only situated in the peripheral and inner walls. Total weight of the panels was $10,489.5 \mathrm{~kg}$ which corresponded to $4.62 \%$ of total construction weight whereas amount of the CLT panel in peripheral wall was only $1300.5 \mathrm{~kg}$ higher than that in inner walls.

\subsection{Holistic Life Cycle Impact Assessment}

Second, the impact assessment of the structure was performed. Table 2 summarizes the environmental impact of the whole structure. The climate change impact category was divided into fossil carbon emissions, biogenic carbon emissions, carbon uptake by vegeta- 
tion, and carbon emissions resulting from land use and transformation. Biomass uptake of carbon was detected as the most represented part of the climate change category accounting for $-87.96 \mathrm{t} \mathrm{CO}_{2}$ eq. Carbon emissions from fossil sources, biogenic decomposition, and LUT activities reached $76.28 \mathrm{t}, 19.86 \mathrm{t}$, and $291.41 \mathrm{~kg}$ of $\mathrm{CO}_{2}$ eq, respectively.

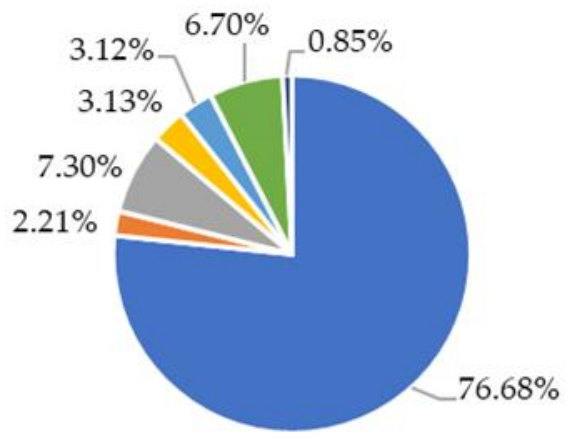

(a)

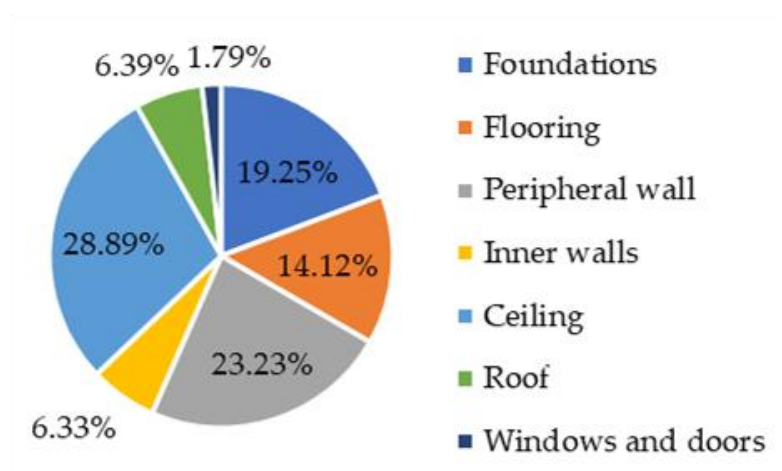

(b)

Figure 6. Distribution of construction components within the whole construction: (a) weight distribution; (b) volume distribution.

Table 2. Total life cycle impact assessment results.

\begin{tabular}{|c|c|c|c|}
\hline Impact Category & Unit & Impact Per Whole Structure & Impact Per $1 \mathrm{~m}^{2}$ of GIA \\
\hline CC-fossil & $\mathrm{kgCO}_{2} \mathrm{eq}$ & $76,279.05$ & 513.66 \\
\hline CC-biogenic ${ }^{1}$ & $\mathrm{kgCO}_{2} \mathrm{eq}$ & $19,861.54$ & 133.75 \\
\hline CC-carbon uptake ${ }^{2}$ & $\mathrm{kgCO}_{2} \mathrm{eq}$ & $-87,955.40$ & -592.29 \\
\hline $\mathrm{CC}-\mathrm{LUT}^{3}$ & $\mathrm{kgCO}_{2} \mathrm{eq}$ & 291.41 & 1.96 \\
\hline Acidification & $\mathrm{kg} \mathrm{SO}_{2} \mathrm{eq}$ & 408.76 & 2.75 \\
\hline Eutrophication & $\mathrm{kg} \mathrm{PO}_{4}{ }^{-} \mathrm{eq}$ & 130.84 & 0.88 \\
\hline Photochemical oxidation & kg NMVOC & 346.11 & 2.33 \\
\hline $\mathrm{AD}$ —elements & $\mathrm{kg} \mathrm{Sb} \mathrm{eq}$ & 3.31 & 0.02 \\
\hline AD—fossil fuels & MJ & $837,548.89$ & 5640.06 \\
\hline Water scarcity & $\mathrm{m}^{3} \mathrm{eq}$ & $99,137.69$ & 667.59 \\
\hline
\end{tabular}

${ }^{1}$ involves biogenic emissions of carbon dioxide and methane with emission factors of 1 and $30.5 \mathrm{~kg} \mathrm{CO}_{2}$ eq, respectively. ${ }^{2}$ involves carbon dioxide captures with emission factors of $-1 \mathrm{~kg} \mathrm{CO}_{2}$ eq. ${ }^{3}$ involves emissions of carbon dioxide and methane connected with land transformation with emission factors of 1 and $30.5 \mathrm{~kg} \mathrm{CO}_{2}$ eq, respectively. Note: CC-Climate change; LUT-Land use and transformation; AD—Abiotic depletion; NMVOC—Non-methane volatile organic compounds.

To calculate the carbon balance $\left(\mathrm{CC}_{\text {overall }}\right)$, the following Equation was applied:

$$
\mathrm{CC}_{\text {overall }}=\mathrm{CC}_{\text {fossil }}+\mathrm{CC}_{\text {biogenic }}+\mathrm{CC}_{\text {uptake }}+\mathrm{CC}_{\mathrm{LUT}}
$$

According to Equation (1), by adding carbon emissions (fossil, biogenic, LUT) and removals (carbon uptake), carbon balance equaled $8185.19 \mathrm{~kg} \mathrm{CO}_{2}$ eq. The following subsections describe selected impact categories in more detail.

\subsubsection{Impact on Climate Change}

The subsection compares the impact of construction components within the CC impact categories (Figure 7). LUT category contributed the least to CC. Nonetheless, the greatest impacts were attributed to the peripheral wall $(27.37 \%)$, roof $(19.47 \%)$, windows and doors $(17.04 \%)$, and ceiling $(14.82 \%)$. Foundations, flooring, and inner walls contributed to the total LUT impact of approximately $7 \%$ each. 


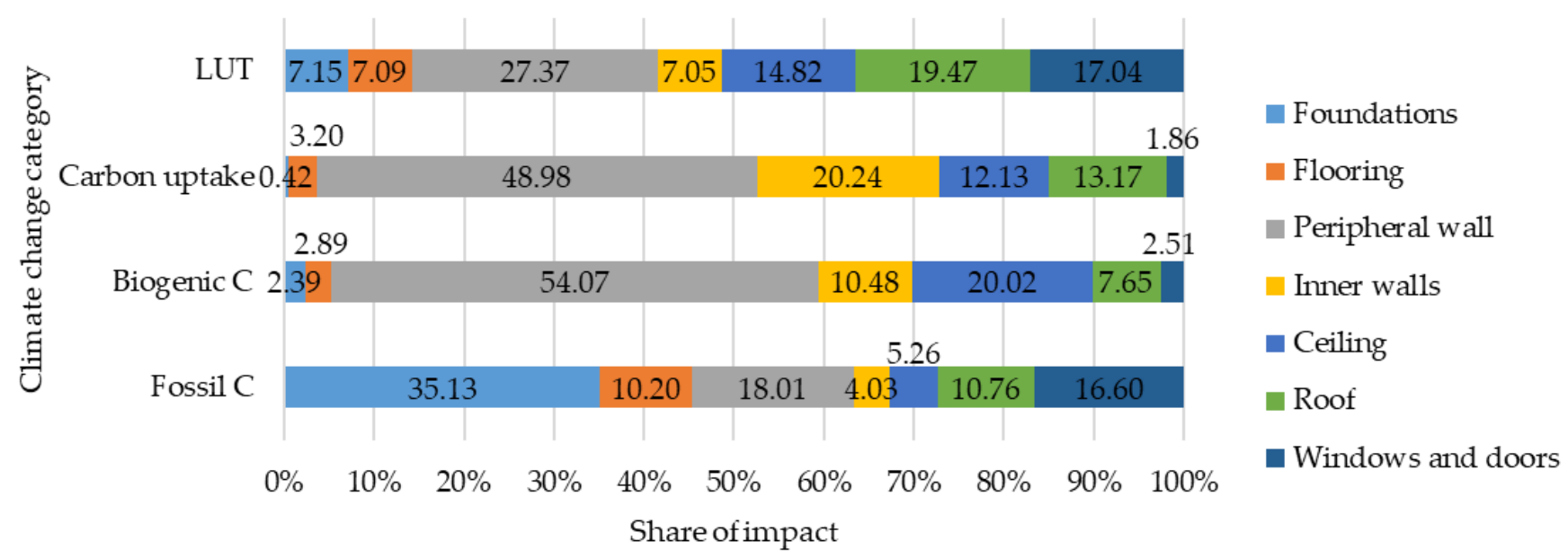

Figure 7. Impact distribution of construction components on climate change.

Nearly half of carbon emissions uptake is related to the peripheral wall (48.98\%). Inner walls corresponded to $20.24 \%$, and roof and ceiling reached 13.17 and $12.13 \%$ of the impact, respectively.

Peripheral wall also dominated in the biogenic carbon emissions (54.07\%). Ceiling and inner walls were responsible for 20.02 and $10.48 \%$ of the impact, respectively.

Foundations reached $35.13 \%$ of the total embodied fossil carbon emissions, followed by the peripheral wall $(18.01 \%)$; windows and doors $(16.60 \%)$; roof $(10.76 \%)$, and flooring $(10.20 \%)$, respectively.

The impact of inner walls was the lowest in the LUT (7.05\%) and fossil carbon emissions category $(4.03 \%)$. Foundations were identified to have the lowest embodied impact in carbon uptake and biogenic carbon emissions equal to 0.42 and $2.39 \%$, respectively.

\subsubsection{Impact on Acidification and Eutrophication}

The share of embodied impact on the above-mentioned categories was relatively balanced (Figure 8). The highest impact resulted from the peripheral wall $(25.89 ; 27.02 \%)$, the second-worst component was detected to be foundations $(22.73 ; 25.42 \%)$, followed by windows and doors $(17.91 ; 14.62 \%)$, and roof $(10.39 ; 9.95 \%)$ for both acidification and eutrophication impact categories, respectively. The share of inner walls on the overall impact was 4.53 and $5.24 \%$, respectively.

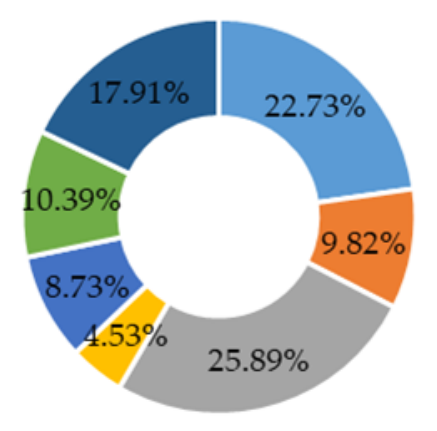

(a)

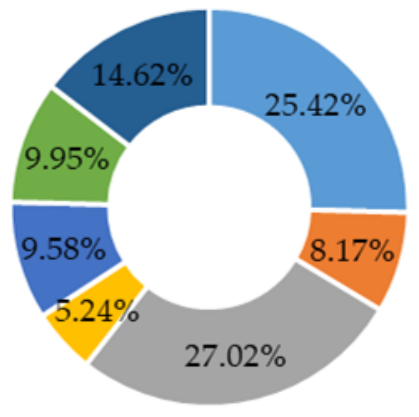

(b)

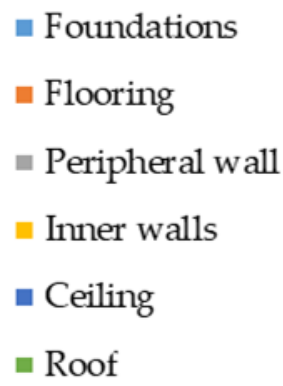

- Windows and doors

Figure 8. Impact distribution of construction components on: (a) acidification; (b) eutrophication.

\subsubsection{Impact on Photochemical Oxidation}

The highest emissions contributing to photochemical oxidation (Figure 9) were identified for foundations $(29.74 \%)$. The rest, precisely $23.26 \%$, was bound to the peripheral wall; $12.86 \%$ resulted from windows and doors manufacture; $10.85 \%$ accounted for flooring, and $10.26 \%$ were connected to the roof. The share of inner walls was the least equaled to $5.75 \%$. 


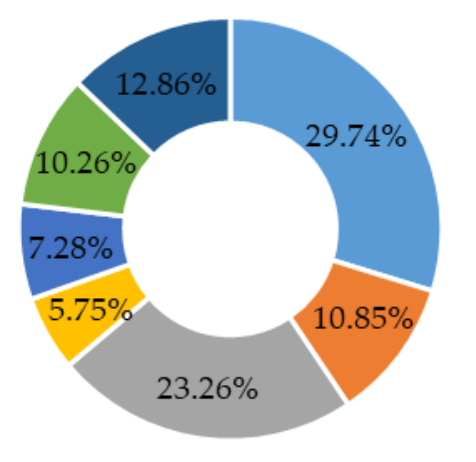

$$
\begin{aligned}
& \text { - Foundations } \\
& \text { - Flooring } \\
& \text { " Peripheral wall } \\
& \text { " Inner walls } \\
& \text { - Ceiling } \\
& \text { - Roof } \\
& \text { - Windows and doors }
\end{aligned}
$$

Figure 9. Impact distribution of construction components on photochemical oxidation.

\subsubsection{Impact on Water Scarcity}

Most of the embodied water consumption was assigned to the peripheral wall $(60.30 \%)$ (Figure 10). Ceiling accounted for $20.91 \%$, and foundations were responsible for $9.12 \%$ of the impact, respectively. Other components reached less than $4 \%$ of the impact, each leaving the inner walls the least damaging part of the studied construction.

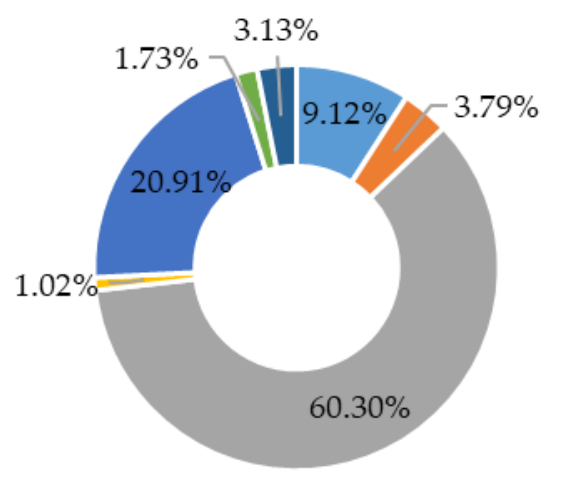

$$
\begin{aligned}
& \text { - Foundations } \\
& \text { - Flooring } \\
& \text { - Peripheral wall } \\
& \text { - Inner walls } \\
& \text { - Ceiling } \\
& \text { - Roof } \\
& \text { - Windows and doors }
\end{aligned}
$$

Figure 10. Impact distribution of construction components on water scarcity.

\subsubsection{Impact on Abiotic Depletion}

Abiotic raw material sources were divided into chemical elements and fossil fuels (Figure 11). The results showed $50.09 \%$ of elements depletion related to the peripheral wall. Ceiling and roof were responsible for 19.03 and $16.45 \%$ of the impact, respectively.

Embodied impact of inner walls was the least, accounting for $2.57 \%$.

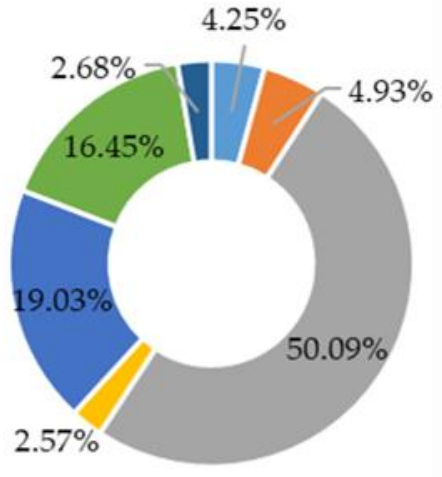

(a)

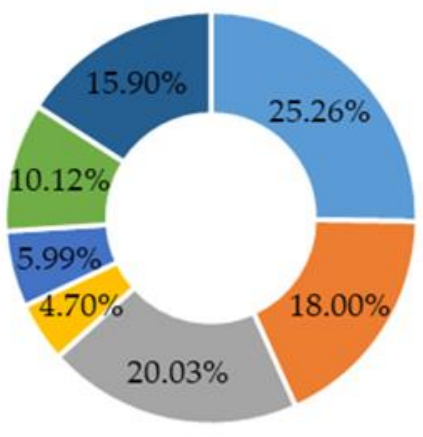

(b)

\section{n Foundations \\ = Flooring \\ n Peripheral wall \\ " Inner walls \\ - Ceiling \\ ॥ Roof \\ - Windows and doors}

Figure 11. Impact distribution of construction components on abiotic depletion: (a) depletion of elements; (b) depletion of fossil fuels. 
The category of fossil fuels depletion was rather leveled in comparison with the previous one. A quarter of the impact was bound to foundations (25.26\%), and a fifth related to the peripheral wall (20.03\%). Flooring and windows and doors reached 18.00 and $15.90 \%$, respectively, of the embodied impact. Similar to the previous categories, inner walls were found to be the best construction component reaching only $4.70 \%$ of the total impact on fossil fuels depletion.

\subsubsection{Specification of the Most and the Least Contributing Construction Components}

Up to this point, it was still not obvious which construction materials contributed the most to the specific environmental impact categories. Thus, an overview of components ranking within individual impact categories was performed (Table 3). Foundations and peripheral walls were the only components ranked in the first place represented with a ratio of 3:7, respectively. The last positions were occupied up to $80 \%$ by inner walls, and the rest was assigned to foundations. Other components were placed in between the stated ranks. Therefore, the above-mentioned components were selected for a closer impact assessment.

Table 3. Ranking of construction components according to their embodied impact within the impact categories.

\begin{tabular}{|c|c|c|c|c|c|c|c|}
\hline \multirow{2}{*}{ Impact Category } & \multicolumn{7}{|c|}{ Rank (No. 1 Refer to the Highest Contribution) } \\
\hline & 1 & 2 & 3 & 4 & 5 & 6 & 7 \\
\hline CC-fossil & Found. & PW & $\mathrm{W} / \mathrm{D}$ & Roof & Flooring & Ceiling & IW \\
\hline CC-biogenic & PW & Ceiling & IW & Roof & Flooring & $\mathrm{W} / \mathrm{D}$ & Found. \\
\hline CC-carbon uptake & PW & IW & Roof & Ceiling & Flooring & $\mathrm{W} / \mathrm{D}$ & Found. \\
\hline CC-LUT & PW & Roof & $\mathrm{W} / \mathrm{D}$ & Ceiling & Found. & Flooring & IW \\
\hline Acidification & PW & Found. & $\mathrm{W} / \mathrm{D}$ & Roof & Flooring & Ceiling & IW \\
\hline Eutrophication & PW & Found. & $\mathrm{W} / \mathrm{D}$ & Roof & Ceiling & Flooring & IW \\
\hline Photochemical oxidation & Found. & PW & $\mathrm{W} / \mathrm{D}$ & Flooring & Roof & Ceiling & IW \\
\hline AD_elements & PW & Ceiling & Roof & Flooring & Found. & $\mathrm{W} / \mathrm{D}$ & IW \\
\hline AD_fossil fuels & Found. & PW & Flooring & $\mathrm{W} / \mathrm{D}$ & Roof & Ceiling & IW \\
\hline Water scarcity & PW & Ceiling & Found. & Flooring & $\mathrm{W} / \mathrm{D}$ & Roof & IW \\
\hline
\end{tabular}

Note: Found—foundations; PW—peripheral wall; W/D—windows and doors; IW—inner walls.

First, an impact assessment of the peripheral wall was performed (Figure 12). In most of the impact categories, light density fibreboard (LDF; according to ecoinvent database it referred to Fiberboard, soft) was found to bear the highest embodied impact. The positive impact of CLT in carbon emissions removal was detected in the CC-carbon uptake category. Steel joints were the most emission contributing materials in fossil carbon emissions and the depletion of fossil fuels.

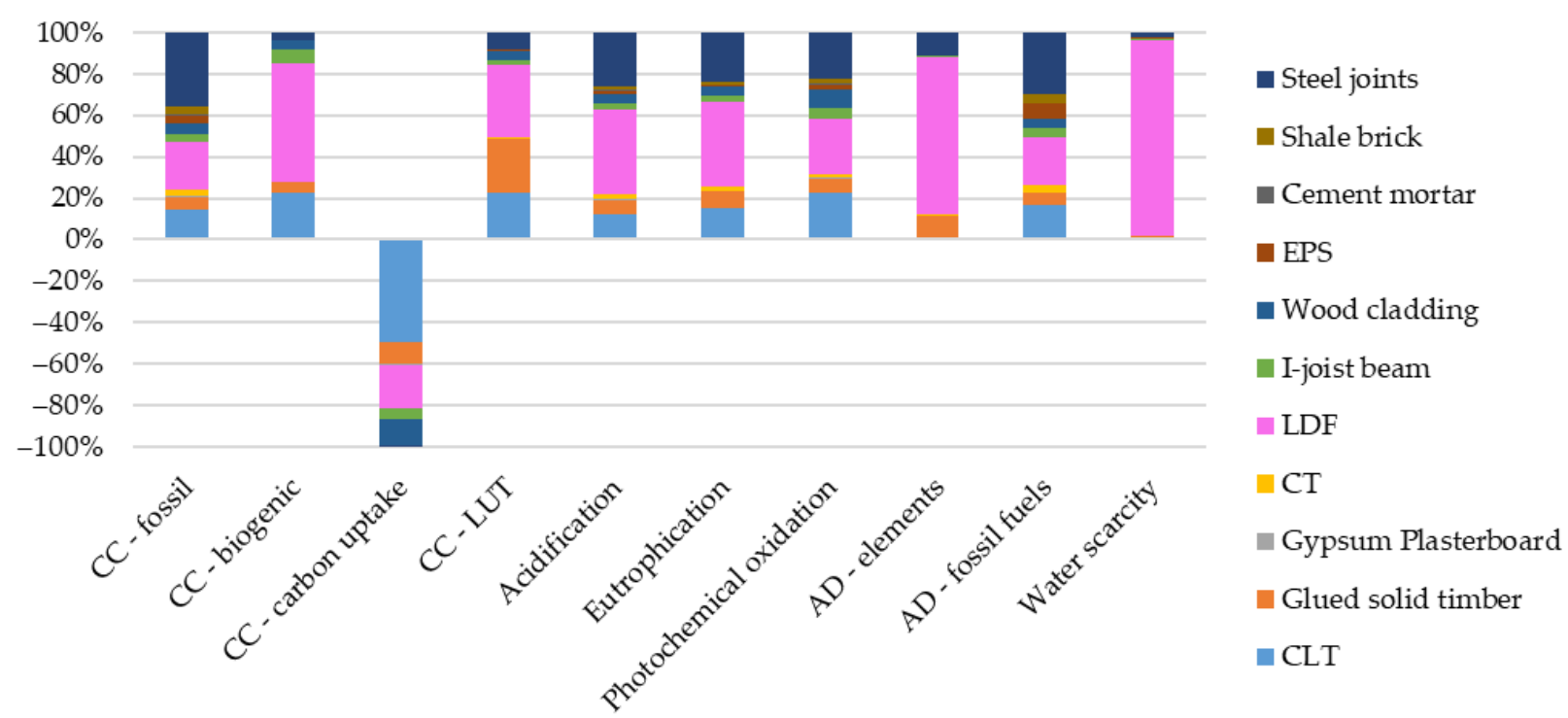

Figure 12. Impact assessment of peripheral wall construction materials. 
If we assumed different concrete types in foundations as separate construction materials, reinforcing steel would be the significant impact contributor within each category (Figure 13). However, if the impact of concrete was added up, it would level or exceed the contribution of reinforcing steel.

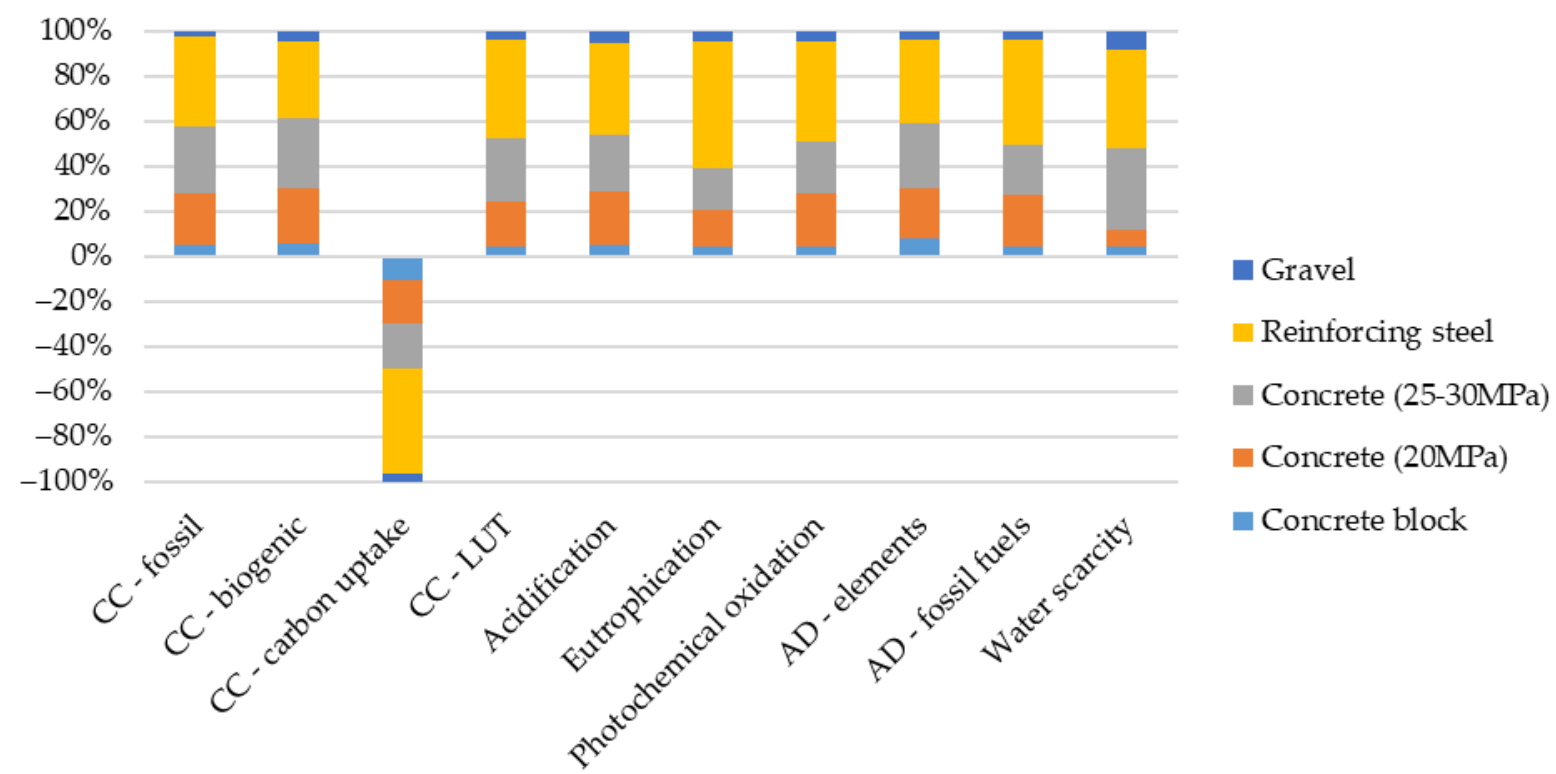

Figure 13. Impact assessment of foundations construction materials.

Assessing the inner walls material contribution, CLT was found to bear most of the impact in all categories except depletion of elements led by glued solid timber (Figure 14). Ceramic tiles contribution in the stated category was the second highest.

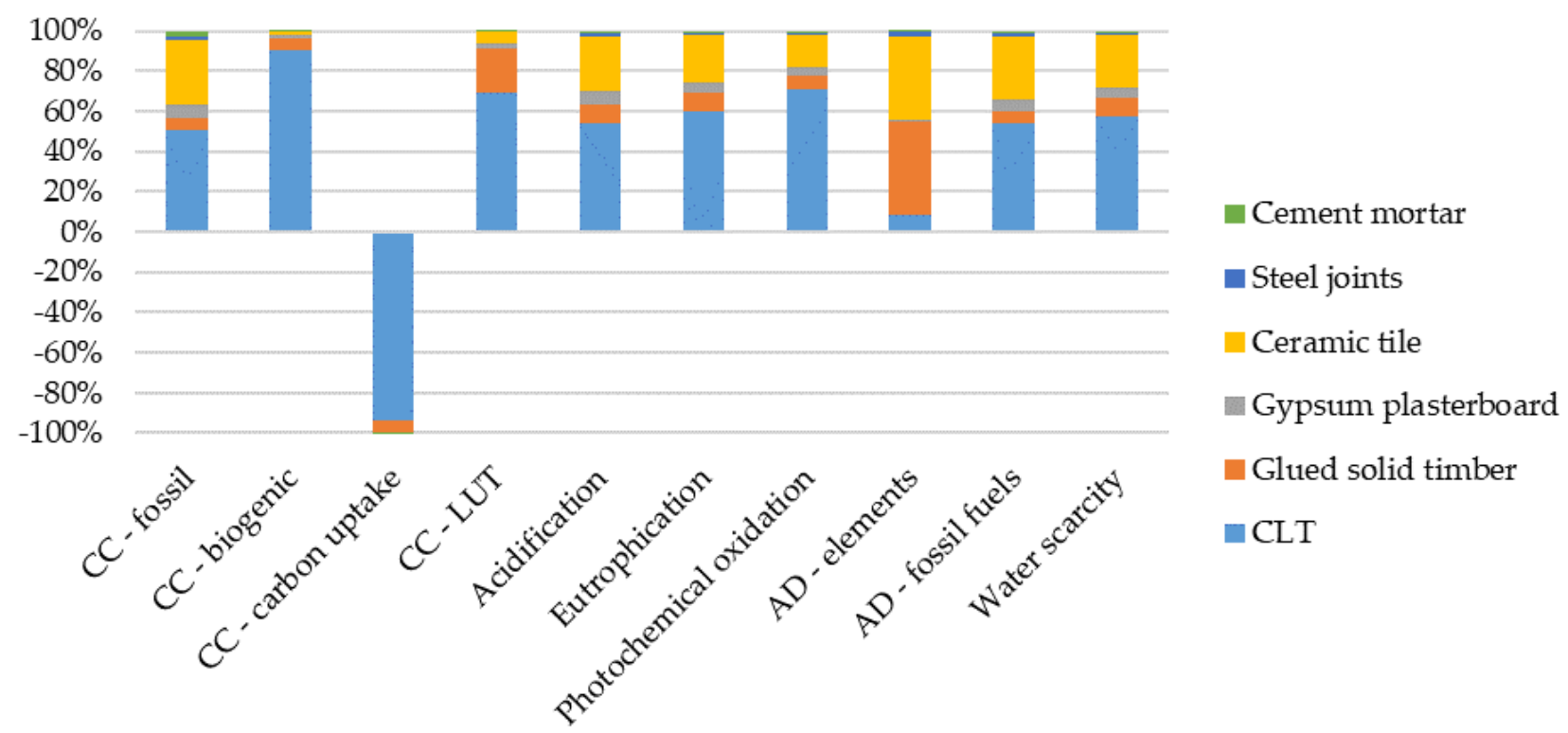

Figure 14. Impact assessment of inner walls construction materials.

\subsection{Sensitivity Analysis}

As LDF and CLT were found to be the most impact contributing construction materials within peripheral and inner walls, a sensitivity analysis was conducted to completely substitute these materials. 
MHM panel was selected to replace the CLT panel within the whole construction. The new construction material differed from the original in manufacturing technology and dimensions. Instead of the CLT panels, which were glued, separate layers of MHM panels were nailed. The thickness of the peripheral and inner wall panels was adjusted to 170 and $120 \mathrm{~mm}$, respectively. The design of the structure using MHM panels preserving the same gross external area reduced the gross and the net internal area of the construction, improving the thermaltechnical properties of the peripheral walls, on the other hand. The heat transfer coefficient of the peripheral wall using MHM panel was $0.133 \mathrm{~W} \cdot \mathrm{m}^{-2} \mathrm{~K}^{-1}$. Substitution of CLT by the MHM panel only changed the load-bearing structure. Structural layers remained the same. The change in the impact after substitution of CLT panel (Table 4) showed minimal differences in peripheral wall environmental performance. However, the impact of inner walls rose from $9.33-30.91 \%$ in fossil fuel depletion and biogenic carbon emissions, respectively. Water scarcity was the only category reporting a decrease of $-12.17 \%$ of the impact. The most significant reduction of $-16.16 \%$ in the impact of other components was noticed in the carbon uptake category.

Table 4. MHM panel instead of CLT panel—sensitivity analysis results.

\begin{tabular}{|c|c|c|c|c|c|c|c|}
\hline Impact Category & Foundations & Flooring & $\begin{array}{c}\text { Peripheral } \\
\text { Wall }\end{array}$ & Inner Walls & Ceiling & Roof & $\begin{array}{l}\text { Windows } \\
\text { and Doors }\end{array}$ \\
\hline CC-fossil & $-1.05 \%$ & $-1.05 \%$ & $1.83 \%$ & $12.08 \%$ & $-1.05 \%$ & $-1.05 \%$ & $-1.05 \%$ \\
\hline CC-biogenic & $-8.67 \%$ & $-8.67 \%$ & $-0.31 \%$ & $30.91 \%$ & $-8.67 \%$ & $-8.67 \%$ & $-8.67 \%$ \\
\hline CC-carbon uptake & $-16.16 \%$ & $-16.16 \%$ & $1.05 \%$ & $22.02 \%$ & $-16.16 \%$ & $-16.16 \%$ & $-16.16 \%$ \\
\hline CC-LUT & $-5.23 \%$ & $-5.23 \%$ & $4.79 \%$ & $30.03 \%$ & $-5.23 \%$ & $-5.23 \%$ & $-5.23 \%$ \\
\hline Acidification & $-1.81 \%$ & $-1.81 \%$ & $1.77 \%$ & $17.69 \%$ & $-1.81 \%$ & $-1.81 \%$ & $-1.81 \%$ \\
\hline Eutrophication & $-2.42 \%$ & $-2.42 \%$ & $2.18 \%$ & $19.99 \%$ & $-2.42 \%$ & $-2.42 \%$ & $-2.42 \%$ \\
\hline $\begin{array}{c}\text { Photochemical } \\
\text { oxidation }\end{array}$ & $-3.07 \%$ & $-3.07 \%$ & $3.70 \%$ & $22.94 \%$ & $-3.07 \%$ & $-3.07 \%$ & $-3.07 \%$ \\
\hline AD_elements & $-1.19 \%$ & $-1.19 \%$ & $0.10 \%$ & $19.97 \%$ & $-1.19 \%$ & $-1.19 \%$ & $-1.19 \%$ \\
\hline AD—fossil fuels & $-0.91 \%$ & $-0.91 \%$ & $1.23 \%$ & $9.33 \%$ & $-0.91 \%$ & $-0.91 \%$ & $-0.91 \%$ \\
\hline Water scarcity & $0.32 \%$ & $0.32 \%$ & $0.00 \%$ & $-12.17 \%$ & $0.32 \%$ & $0.32 \%$ & $0.32 \%$ \\
\hline
\end{tabular}

According to the previous findings, insulation played a substantial role in the impact of peripheral wall concurrently affecting the whole construction. Therefore, for sensitivity analysis purposes, stone wool was chosen as a replacement for LDF-the most contributing construction material by embodied impact of the peripheral wall. The adjusted peripheral wall impact (Table 5) showed a reduction in all impact categories with the lowest change of $-11.89 \%$ in carbon uptake up to $-85.76 \%$ in water scarcity. The last-mentioned category also reported a remarkable increase in the impact of other components of $130.26 \%$.

Table 5. Stone wool insulation instead of LDF—sensitivity analysis results.

\begin{tabular}{|c|c|c|c|c|c|c|c|}
\hline Impact Category & Foundations & Flooring & $\begin{array}{c}\text { Peripheral } \\
\text { Wall }\end{array}$ & Inner Walls & Ceiling & Roof & $\begin{array}{l}\text { Windows } \\
\text { and Doors }\end{array}$ \\
\hline CC-fossil & $4.21 \%$ & $4.21 \%$ & $-19.16 \%$ & $4.21 \%$ & $4.21 \%$ & $4.21 \%$ & $4.21 \%$ \\
\hline CC-biogenic & $44.87 \%$ & $44.87 \%$ & $-38.12 \%$ & $44.87 \%$ & $44.87 \%$ & $44.87 \%$ & $44.87 \%$ \\
\hline CC-carbon uptake & $11.42 \%$ & $11.42 \%$ & $-11.89 \%$ & $11.42 \%$ & $11.42 \%$ & $11.42 \%$ & $11.42 \%$ \\
\hline $\mathrm{CC}-\mathrm{LUT}$ & $10.43 \%$ & $10.43 \%$ & $-27.67 \%$ & $10.43 \%$ & $10.43 \%$ & $10.43 \%$ & $10.43 \%$ \\
\hline Acidification & $11.70 \%$ & $11.70 \%$ & $-33.49 \%$ & $11.70 \%$ & $11.70 \%$ & $11.70 \%$ & $11.70 \%$ \\
\hline Eutrophication & $12.28 \%$ & $12.28 \%$ & $-33.18 \%$ & $12.28 \%$ & $12.28 \%$ & $12.28 \%$ & $12.28 \%$ \\
\hline Photochemical oxidation & $6.59 \%$ & $6.59 \%$ & $-21.76 \%$ & $6.59 \%$ & $6.59 \%$ & $6.59 \%$ & $6.59 \%$ \\
\hline AD_elements & $61.44 \%$ & $61.44 \%$ & $-61.22 \%$ & $61.44 \%$ & $61.44 \%$ & $61.44 \%$ & $61.44 \%$ \\
\hline AD_fossil fuels & $4.75 \%$ & $4.75 \%$ & $-18.95 \%$ & $4.75 \%$ & $4.75 \%$ & $4.75 \%$ & $4.75 \%$ \\
\hline Water scarcity & $130.26 \%$ & $130.26 \%$ & $-85.76 \%$ & $130.26 \%$ & $130.26 \%$ & $130.26 \%$ & $130.26 \%$ \\
\hline
\end{tabular}

By applying the results of sensitivity analyses to the overall impact of the construction (Table 6), it was found that change in the load-bearing system slightly increased the environmental performance of the structure, primarily visible in biogenic carbon emissions (9.49\%). However, carbon uptake was improved by $19.27 \%$, which enhanced the carbon balance to negative signs leading to the predominance of carbon removals over emissions. 
This construction composition created a carbon-negative construction of embodied carbon emissions equaled to $-5764.22 \mathrm{~kg} \mathrm{CO}_{2}$ eq respecting Equation (1) of carbon balance.

Table 6. Overall changes in the embodied impact of the construction after substituting the most relevant construction materials.

\begin{tabular}{cccc}
\hline Impact Category & Original Impact & $\begin{array}{c}\text { Change in Impact after } \\
\text { Substituting CLT by } \\
\text { MHM Panel }\end{array}$ & $\begin{array}{c}\text { Change in Impact after } \\
\text { Substituting LDF by } \\
\text { Stone Wool }\end{array}$ \\
\hline CC-fossil & $100.00 \%$ & $1.06 \%$ & $-4.04 \%$ \\
CC-biogenic & $100.00 \%$ & $9.49 \%$ & $-30.97 \%$ \\
CC-carbon uptake & $100.00 \%$ & $19.27 \%$ & $-10.25 \%$ \\
CC-LUT & $100.00 \%$ & $5.52 \%$ & $-9.44 \%$ \\
Acidification & $100.00 \%$ & $1.84 \%$ & $-10.48 \%$ \\
Eutrophication & $100.00 \%$ & $2.47 \%$ & $-10.94 \%$ \\
Photochemical oxidation & $100.00 \%$ & $3.17 \%$ & $-6.19 \%$ \\
AD-elements & $100.00 \%$ & $1.21 \%$ & $-38.06 \%$ \\
AD-fossil fuels & $100.00 \%$ & $0.92 \%$ & $-4.53 \%$ \\
Water scarcity & $100.00 \%$ & $-0.32 \%$ & $-56.57 \%$ \\
\hline
\end{tabular}

Substitution of LDF by stone wool reduced the impact of construction in all categories by $4.04 \%$ (fossil carbon emissions), and up to $56.57 \%$ (water scarcity). The outcome of the carbon balance regarding Equation (1) was $8228.71 \mathrm{~kg} \mathrm{CO}_{2}$ eq, which was approximately $3 \%$ lower than the original one.

\section{Discussion}

The study focused on the comparison of the embodied environmental impact of individual construction components. The initial evaluation was aimed at determining the weight and volume distribution within the construction. In terms of the first mentioned, $76.68 \%$ of the overall construction weight was concentrated in the foundations. Timber constructions consist of several construction materials. In addition, the weight of the inner walls was about $57 \%$ lower than that of the peripheral wall. That was caused by relatively simpler material composition and lower thickness of the inner walls (excluding insulation and outdoor cladding). CLT panels constituted only $4.62 \%$ of the total construction weight. The biggest component by volume represented ceiling $(28.89 \%)$, which was about $5 \%$ higher than peripheral wall (23.23\%). The components volume could be explained by the relatively large openings for windows and entrance door $\left(34.5 \mathrm{~m}^{2}\right)$ and the rather large ceiling thickness due to the insulation layer of $400 \mathrm{~mm}$.

The impact assessment of the construction was set (Table 2). As one of the biggest concerns in the construction industry is focused on climate change mitigation [29], a carbon balance was calculated to measure the embodied carbon of the structure. The considered construction composition carbon balance was $57.08 \mathrm{~kg} \mathrm{CO} 2 \mathrm{eq} / \mathrm{m}^{2}$ of GIA, which agreed with the embodied carbon emissions of low-rise timber constructions [21].

After a primary analysis (Table 2), impact analyses on the share of the building components within the individual impact categories were carried out (Figures 7-11). Based on the findings, a table was created ranking the components from the most to the least burdensome (Table 3). Subsequently, the best and the worst components were chosen for a detailed impact assessment to identify materials responsible for such impact.

Foundations and peripheral wall were identified as the worst components. The impact contribution of foundations was caused by concrete and reinforcing steel. Except for water scarcity and depletion of elements, the contribution of foundations on individual impact categories was higher than $22 \%$, which roughly matches the findings of Ondova et al. [30]. LDF was marked as the main environmental impact contributor of the peripheral wall component causing the majority of the impact on the depletion of elements and water scarcity (Figure 12). The CLT panel reported the greatest impact of the inner walls (Figure 14), which is understandable given that inner walls were composed of a low number of construction materials, and since the panel was the main element of the component. 
To determine the influence of another construction material selection as well as to find out if the CLT panel structure affected the total environmental impact more than the LDF insulation, a sensitivity analysis was performed. The CLT panel was replaced by an MHM panel, which retained the same orthogonal laminar structure and differed in the production technology and material composition (Table 4). The next analysis focused on applying stone wool insulation instead of LDF (Table 5). Afterwards, the comparison of the primary total construction impact and the two substitutions in construction was established (Table 6).

Sensitivity analysis showed that substitution of CLT by MHM panel led to carbonnegative embodied emissions of the construction $\left(-38.82 \mathrm{~kg} \mathrm{CO}\right.$ eq/ $\mathrm{m}^{2}$ of GIA), which might be partly caused by larger dimensions of the MHM panel. However, it should be stated that the manufacturing of the MHM panel was considered on the construction site and did not include auxiliary material and energy inputs for the prefabrication. Therefore, the actual impact of MHM panel manufacturing might be higher. The second analysis showed that the impact on each category was reduced as LDF was replaced by stone wool (Table 6). The most decreased impact was reported on the water scarcity category accounting for an overall construction reduction of $-56.57 \%$ of the impact. The change in the depletion of elements observed was $-38.06 \%$ of that impact. However, introducing abiotic insulation material lowered carbon removals, resulting in an overall carbon balance of almost 3\% compared to the LDF alternative. Therefore, it can be concluded that natural-based construction materials might not be a sustainable solution that complies with the findings of other authors [31,32]. However, future studies might be focused on the application of bark-based panel insulation [33].

Each construction impact might be unique due to its use, specific construction materials, climate conditions, regional markets, etc. [34]. Moreover, the selection of calculation methods, modelling approach, as well as system boundaries vary from study to study [35]. Several limitations were found using this study for comparison purposes with other constructions. First, the assessment was done using attributional modeling based on allocation at the point of substitution [26] used for hot-spot identification of the system under study. Other types of modeling might report different results. Another point is that the study only considered embodied environmental impacts reflecting the burdens of the construction materials manufacture. Other life cycle stages, such as transportation, construction process, use of the building, and the end-of-life, were not assessed. The absence of the assessment of other stages might also be a disadvantage in an overall assessment of the construction while it would enhance or worsen the embodied impact performance when considering the whole life cycle.

\section{Conclusions}

Timber constructions are generally considered sustainable as they bind carbon dioxide in the wood structure and as it is relatively easier to manufacture wood-based construction materials instead of masonry buildings. Efforts to reduce the energy intensity of buildings shift the environmental impact from the operational stage to construction materials. Therefore, the environmental performance of construction becomes highly dependent on the construction materials involved.

The main findings of the paper could be specified as follows:

- The majority of the overall construction weight was located in foundations accounting for $76.68 \%$. CLT panels constituted only $4.62 \%$ of the total construction weight. The biggest component by volume represented ceiling $(28.89 \%)$ due to rather large ceiling thickness due to the insulation layer of $400 \mathrm{~mm}$ followed by the peripheral wall $(23.23 \%)$ with the relatively large openings for windows and entrance door.

- Foundations and peripheral wall were identified as the worst components of the construction in terms of several impact categories. The impact contribution of foundations was mainly caused by concrete and reinforcing steel. LDF was marked as the main environmental impact contributor of the peripheral wall component causing the majority of the impact on the depletion of elements and water scarcity. 
- The considered construction composition carbon balance was $57.08 \mathrm{~kg} \mathrm{CO} 2 \mathrm{eq} / \mathrm{m}^{2}$ of GIA. Sensitivity analysis showed that substitution of CLT by MHM panel led to carbonnegative embodied emissions of the construction ( $-38.82 \mathrm{~kg} \mathrm{CO} 2 \mathrm{eq} / \mathrm{m}^{2}$ of GIA).

- CLT panels were found to be one of the least negative impact contributing construction material. On the other hand, the study showed LDF to contribute the most to the environmental impact of the construction. Moreover, a properly chosen composition of construction materials might result in carbon negative embodied emissions of a building as it was in the case of MHM panels. Future studies might be focused on the application of bark-based panel insulation.

Author Contributions: Conceptualization, R.V. and J.S. (Jozef Stefko); Data curation, R.V.; Formal analysis, R.V. and J.S. (Jozef Stefko); Funding acquisition, J.S. (Jozef Stefko); Investigation, R.V. and P.S.; Methodology, R.V.; Project administration, R.V. and J.S. (Jozef Stefko); Resources, R.V. and J.S. (Jozef Stefko); Software, R.V.; Supervision, J.S. (Jozef Stefko) and J.S. (Jaroslava Stefkova); Validation, R.V., P.S. and J.S. (Jozef Stefko); Visualization, R.V. and P.S.; Writing—original draft, R.V. and J.S. (Jozef Stefko); Writing-review and editing, R.V., J.S. (Jozef Stefko) and J.S. (Jaroslava Stefkova). All authors have read and agreed to the published version of the manuscript.

Funding: We wish to thank the Slovak Research and Development Agency (grant number APVV17-0206) and Scientific Grant Agency of Ministry of Education, Science, Research and Sport of the Slovak Republic (grant number VEGA 1/0717/19).

Institutional Review Board Statement: Not applicable.

Informed Consent Statement: Not applicable.

Data Availability Statement: Additional data on datasets used in this study can be found at https:/ / ecoinvent.org/the-ecoinvent-database/data-releases/ecoinvent-3-7-1/ (accessed on 22 October 2021).

Conflicts of Interest: The authors declare no conflict of interest.

\section{References}

1. United Nations Framework Convention on Climate Change, The Paris Agreement. 2015. Available online: https://unfccc.int/ files/essential_background/convention/application/pdf/english_paris_agreement.pdf (accessed on 22 October 2021).

2. European Commission. The European Green Deal. 2019. Available online: https://eur-lex.europa.eu/resource.html?uri=cellar: b828d165-1c22-11ea-8c1f-01aa75ed71a1.0002.02/DOC_1\&format=PDF (accessed on 22 October 2021).

3. World Green Building Council. Bringing Embodied Carbon Upfront. 2019. Available online: https://www.worldgbc.org/sites/ default/files/WorldGBC_Bringing_Embodied_Carbon_Upfront.pdf (accessed on 21 October 2021).

4. Brandner, R.; Flatscher, G.; Ringhofer, A.; Schickhofer, G.; Thiel, A. Cross laminated timber (CLT): Overview and development. Eur. J. Wood Prod. 2016, 74, 331-351. [CrossRef]

5. American Wood Council. National Design Specification (NDS) for Wood Construction, 2017. ANSI/AWC NDS-2017; American Wood Council: Leesburg, VA, USA, 2017; Available online: https://www.awc.org/pdf/codes-standards/publications/nds/AWCNDS2018-ViewOnly-171117.pdf (accessed on 20 October 2021).

6. Gagnon, S.; Bilek, E.M.; Podesto, L.; Crespell, P. Chapter 1: CLT Introduction to cross-laminated timber. In CLT Handbook: Cross-Laminated Timber; Karacabeyli, E., Brad, D., Eds.; FPInnovations: Pointe-Claire, QC, Canada, 2013; pp. 1-45. Available online: https:/ / www.fpl.fs.fed.us/documnts/pdf2013/fpl_2013_gagnon001.pdf (accessed on 20 October 2021).

7. Santi, S.; Pierobon, F.; Corradini, G.; Cavalli, R.; Zanetti, M. Massive wood material for sustainable building design: The Massiv-Holz-Mauer wall system. J. Wood Sci. 2016, 62, 416-428. [CrossRef]

8. Pierobon, F.; Huang, M.; Simonen, K.; Ganguly, I. Environmental benefits of using hybrid CLT structure in midrise non-residential construction: An LCA-based comparative case study in the U.S. Pacific Northwest. J. Build. Eng. 2019, 26, 100862. [CrossRef]

9. ISO. EN ISO 14040:2006 Environmental Management_Life Cycle Assessment_Principles and Framework; ISO: Geneva, Switzerland, 2006.

10. ISO. EN ISO 14044:2006 Environmental Management—Life Cycle Assessment—Requirements and Guidelines; ISO: Geneva, Switzerland, 2006.

11. ISO. EN 15978:2011 Sustainability of Construction Works-Assessment of Environmental Performance of Buildings_Calculation Method; ISO: Geneva, Switzerland, 2011.

12. ISO. ISO 21931-1:2010 Sustainability in Building Construction—Framerwork for Methods of Assessment of the Environmental Performance of Construction Works_Part 1: Buildings; ISO: Geneva, Switzerland, 2010. 
13. Robertson, A.B.; Lam, F.C.F.; Cole, R.J. A Comparative Cradle-to-Gate Life Cycle Assessment of Mid-Rise Office Building Construction Alternatives: Laminated Timber or Reinforced Concrete. Buildings 2012, 2, 245-270. [CrossRef]

14. Liu, Y.; Guo, H.; Sun, C.; Chang, W.-S. Assessing Cross Laminated Timber (CLT) as an Alternative Material for Mid-Rise Residential Buildings in Cold Regions in China-A Life-Cycle Assessment Approach. Sustainability 2016, 8, 1047. [CrossRef]

15. Environmental Product Declaration. CLT (Cross Laminated Timber). The Norwegian EPD Foundation. 2020. Available online: https: / / www.epd-norge.no/getfile.php/1316508-1607949248/EPDer/Byggevarer/Heltreprodukter/NEPD-2587-131 4_CLT--Cross-Laminated-Timber-.pdf (accessed on 20 October 2021).

16. Chen, Z.; Gu, H.; Bergman, R.D.; Liang, S. Comparative Life-Cycle Assessment of a High-Rise Mass Timber Building with an Equivalent Reinforced Concrete Alternative Using the Athena Impact Estimator for Buildings. Sustainability 2020, $12,4708$. [CrossRef]

17. Consortium for Research on Renewable Industrial Materials. CORRIM REPORT—Life Cycle Assessment of Cross Laminated Timbers Produced in Oregon. 2018. Available online: https://corrim.org/wp-content/uploads/2019/02/Life-Cycle-Assessmentof-Oregon-Cross-Laminated-Timber.pdf (accessed on 20 October 2021).

18. Balasbaneh, A.T.; Sher, W. Comparative sustainability evaluation of two engineered wood-based construction materials: Life cycle analysis of CLT versus GLT. Build. Environ. 2021, 204, 108112. [CrossRef]

19. Chen, C.X.; Pierobon, F.; Ganguly, I. Life Cycle Assessment (LCA) of Cross-Laminated Timber (CLT) Produced in Western Washington: The Role of Logistics and Wood Species Mix. Sustainability 2019, 11, 1278. [CrossRef]

20. Leskovar, V.Ž.; Žigart, M.; Premrov, M.; Lukman, R.K. Comparative assessment of shape-related cross-laminated timber building typologies focusing on environmental performance. J. Clean. Prod. 2019, 216, 482-494. [CrossRef]

21. Bahramian, M.; Yetilmezsoy, K. Life cycle assessment of the building industry: An overview of two decades of research (1995-2018). Energy Build. 2020, 219, 109917. [CrossRef]

22. Inardex, Ltd. Available online: https://inardex.sk/rodinne-domy/katalog/prizemne-domy-podorysy/001-s/001-s-magnolia/ (accessed on 13 September 2021).

23. STN 73 0540-2+Z1+Z2 (2019). Thermal Protection of Buildings. In Thermal Performance of Buildings and Components-Part 2: Functional Requirements; Slovak Technical Standards: Bratislava, Slovakia, 2012.

24. EN 15804+A1 (2013). Sustainability of Construction Works. In Environmental Product Declarations. Core Rules for the Product Category of Construction Products; European Committee for Standardization: Bruxelles, Belgium, 2012.

25. Goedkoop, M.; Oele, M.; Leijting, J.; Ponsioen, T.; Meijer, E. Introduction to LCA with SimaPro; PRé Consultants: Amersfoort, The Netherlands, 2013; p. 80. Available online: https: / / www.pre-sustainability.com/download/SimaPro8IntroductionToLCA.pdf (accessed on 7 July 2021).

26. Wernet, G.; Bauer, C.; Steubing, B.; Reinhard, J.; Moreno-Ruiz, E.; Weidema, B. The ecoinvent database version 3 (part I): Overview and methodology. Int. J. Life Cycle Assess. 2016, 21, 1218-1230. [CrossRef]

27. IPCC Climate Change 2013: The Physical Science Basis. In Contribution of Working Group I to the Fifth Assessment Report of the Intergovernmental Panel on Climate Change; Stocker, T.F.; Qin, D.; Plattner, G.-K.; Tignor, M.; Allen, S.K.; Boschung, J.; Nauels, A.; Xia, Y.; Bex, V.; Midgley, P.M. (Eds.) Cambridge University Press: Cambridge, UK; New York, NY, USA, 2013; p. 1535. Available online: https://www.ipcc.ch/site/assets/uploads/2018/02/WG1AR5_all_final.pdf (accessed on 10 November 2021).

28. PRé Consultants. SimaPro Database Manual—Methods Library; PRé Consultants: Amersfoort, The Netherlands, 2021; p. 98. Available online: https:/ / simapro.com/wp-content/uploads/2021/07/DatabaseManualMethods920.pdf (accessed on 10 November 2021).

29. Cabeza, L.F.; Boquera, L.; Chàfer, M.; Vérez, D. Embodied energy and embodied carbon of structural building materials: Worldwide progress and barriers through literature map analysis. Energy Build. 2021, 231, 110612. [CrossRef]

30. Ondová, M.; Eštoková, A.; Fabianová, M. Reducing the carbon footprint in the foundations structures of masonry family houses. Sel. Sci. Pap. J. Civil. Eng. 2020, 15, 55-62. [CrossRef]

31. Vanova, R.; Vlcko, M.; Stefko, J. Life Cycle Impact Assessment of Load-Bearing Straw Bale Residential Building. Materials 2021, 14, 3064. [CrossRef] [PubMed]

32. Ata-Ali, N.; Penandés-Plà, V.; Martínez-Muñoz, D.; Yepes, V. Recycled versus non-recycled insulation alternatives: LCA analysis for different climatic conditions in Spain. Resour. Conserv. Recycl. 2021, 175, 105838. [CrossRef]

33. Kristak, L.; Ruziak, I.; Tudor, E.M.; Barbu, M.C.; Kain, G.; Reh, R. Thermophysical Properties of Larch Bark Composite Panels. Polymers 2021, 13, 2287. [CrossRef] [PubMed]

34. Cabeza, L.F.; Rincón, L.; Vilariño, V.; Pérez, G.; Castell, A. Life cycle assessment (LCA) and life cycle energy analysis (LCEA) of buildings and the building sector: A review. Renew Sustain. Energy Rev. 2014, 29, 394-416. [CrossRef]

35. Anand, C.K.; Amor, B. Recent developments, future challenges and new research directions in LCA of buildings: A critical review. Renew Sustain. Energy Rev. 2017, 67, 408-416. [CrossRef] 